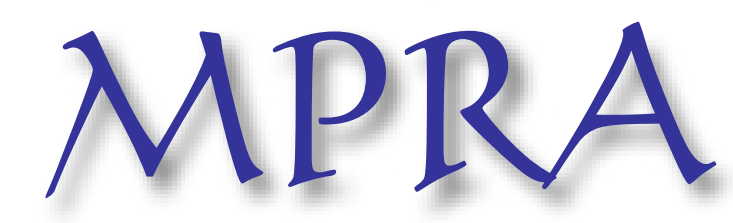

Munich Personal RePEc Archive

\title{
GAME INFORMATION, LOCAL HEROES, AND THEIR EFFECT ON ATTENDANCE: THE CASE OF THE JAPANESE BASEBALL LEAGUE
}

yamamura, eiji

28 April 2008

Online at https://mpra.ub.uni-muenchen.de/10303/

MPRA Paper No. 10303, posted 06 Sep 2008 09:21 UTC 


\title{
GAME INFORMATION, LOCAL HEROES, AND THEIR EFFECT ON
} ATTENDANCE: THE CASE OF THE JAPANESE BASEBALL

\section{LEAGUE.}

\section{EIJI YAMAMURA}

\begin{abstract}
Can professional sports teams develop their fan base and increase attendance by using players from their same hometown? In the Japanese Professional Baseball League, the starting pitcher is announced prior to the game in the Pacific League but not in the Central League. Considering characteristics of starting pitchers such as their hometown and salary, and comparing the Pacific and the Central League, I attempt to investigate how and to what extent the release of information concerning a starting pitcher prior to the game affects attendance. My major findings are as follows: (1) In the Pacific League, the salary of the home team's starting pitcher is positively related to attendance, while that of the visiting team is not. (2) In the Central League, neither the salary of the home team's starting pitcher nor that of the visiting team's affect attendance. (3) In the case of the Pacific League, the positive effect of salary on attendance increases when the home team's starting pitcher is from the same hometown. (JEL : L83, Z13)
\end{abstract}




\section{INTRODUCTION}

Demand for professional sports is one of the major issues in the filed of sports economics and a large amount of research has attempted to ascertain the determinants of attendance for baseball games (e.g., Bruggink and Eaton 1996; Burdekin and Idson 1991; Hill et al. 1982; Hunt and Lewis 1976; Kahane and Shmanske 1997; Knowles et al. 1992; Noll 1974; Schmidt and Berri 2001, 2002, 2004). It is generally acknowledged that information on the quality of goods is very important for consumer decision making. For instance, the recent performance of the home and visiting teams and, hence, their current rankings are regarded as the main factor determining the quality of a game. In addition, the likelihood that a star player will take part in a game is considered to affect fans' perceptions of game quality not only due to increase in the winning probability when a star participates in a game but also because of the star effect stemming from imperfect substitution (Rosen 1981). In other words, as stated by Gwartney and Haworth (1974), "Outstanding players are thought to exert an additional impact on attendance because customers like to observe players of exceptional ability, even if they play for a 'losing team"'. Furthermore, the degree of a star player's popularity appears to depend on the town a game is held since the star player would be more attractive to fans from the same hometown. This is somewhat analogous to customer racial discrimination in the baseball market (e.g., Andersen and La Croix 1991; Irani 1996; Kahn and Sherer 1988; Nardinelli and Simon 1990) ${ }^{1}$. The composition of the starting roster and the town where the game is held are closely related to game quality. Previous information about the starting players is thus very important when the demand for the game is considered.

Those who spend a lot of time in informal conversation and camaraderie are termed schmoozers by Putnam (Putnam 2000, Ch6). Informal social connection, which is spontaneous and flexible, formed through exchange between schmoozers leads local people to enjoy life with others. For instance, in a society with well-formed connections between friends and neighbors, schmoozers are more likely to attend civic-minded or

1 Becker (1971) was the first to theoretically account for the phenomenon of discrimination in the market. 
local events, resulting in further interpersonal exchange. A game in which fans can enjoy the performance of a 'local star' is regarded as a sort of civic event. That is, familiarity with a home team's players should increase a fan's enjoyment of the game, thereby increasing attendance (Kahane and Shmanske 1997). Accordingly, informal social connection induces schmoozers to attend the game if they know that a player coming from their home town is a starting member. It follows that informal social connections appear to enlarge the 'local star' effect and play a crucial role in increasing game attendance.

The Japanese Professional Baseball League ( JPBL) has a two league system, which is comprised of the Pacific and the Central League (La Croix and Kawaura 1999, Yamamura and Shin 2008a, 2008b). In the Pacific League the starting pitcher is announced in advance of a game while in the Central League they are not. Compared to other positions, pitchers vary in each game. This feature causes game quality to rely considerably on the starting pitcher. Due to the different systems, fans can obtain information concerning game quality of the Pacific League games but not Central League games, resulting in a difference of game demand behaviors between them. Under such conditions, the natural experiment of JPBL allows me to compare people with information on game quality to ones without it. Using the panel data of JPBL game attendance during the 2005-2007 period, this research attempts to analyze how and to what extent the different systems between the two leagues have an influence on game attendance through the availability or unavailability of information prior to games and informal social connections.

\section{CONDITIONS OF THE JAPANESE PROFESSIONAL BASEBALL LEAGUE}

In the post-war period, Japan's unprecedented economic growth resulted in increasing demands for the leisure industry. The JPBL has clearly been one of the most popular segments of the leisure industry. The JPBL was inaugurated in 1936 comprising 7 teams in one league. In 1950, JPBL was divided into 2 leagues, 
the Central League (CL) and the Pacific League (PL) (La Croix and Kawaura 1999).

The Yomiuri Giants of the Central League have consistently dominated the JPBL and assured its supremacy. The Giants are the premier team, similar to the New York Yankees in Major League Baseball ${ }^{2}$. The development and diffusion of broadcasting has also increased public interest in the JPBL, particularly in the Giants $^{3}$. Not only fans, but also anti-fans of the Giants are interested in Giants games via broadcasts of baseball games. Necessarily, other Central League teams have been able to attract fans' attentions and thereby increase attendance from games against the Giants. With respect to fan popularity, as provided in the first row of Table 1, the mean value of attendance at Pacific League games is smaller by approximately 7,000 compared to that of Central League games, which is statistically significant at the $1 \%$ level. Consistent with conjecture, this indicates that the Central League is more popular than the Pacifica League. The relationship between the Central League and the Pacific League appears to be similar to that between the American and National Leagues in Major League Baseball. As for population and per capita income where games were held, looking at the bottom row and the second to the bottom row of Table 1 reveals that those of the Central League are significantly larger than the Pacific League. This indicates that the Central League hometowns are larger than those of the Pacific League, suggesting the latent demand for the Central League games is larger. Inevitably, the extent to which owners and industry insiders made efforts to offer services to the fans has been different between the Central League and the Pacific League (Yamamura and Shin 2008a). A structure in which the Central League teams depend upon the Giants for popularity rather than their own efforts has persisted over a long period of time (Kobayashi 2004).

In an attempt to increase their popularity, the Pacific League has adopted various systems which the Central League has not adopted. For instance, in the split season system adopted in the 1973-1983 period, the

2 It is said that the Giants' yearly revenue has reached 300 billion yen, nearly equivalent that of the New York Yankees (Kobayashi 2004, p.200).

3 Almost all games of the Giants were broadcast nationwide because the Giants owner and sponsor is the Yomiuri Group, a newspaper publishing company that holds subsidiary companies including the TV broadcasting company, Nihon Television. 
winners of the first and second halves of the season compete in a playoff to determine the Pacific League winner of the year. The practice of releasing the name of the starting pitcher prior to a game began in 1985 . Although, from 1985 to 1993 this practice was applicable only Sunday games; after 1994 the starting pitcher of all games was announced in advance. As discovered by Yamamura and Shin (2008a), the gap of attendance between the two leagues did not narrow, at least until the mid-1980s. Subsequently, a rapid catch up then followed, particularly during the period 1985-1992, although the difference in attendance numbers continued to exist after even 2005 (Table 1). Based on this I derive argue that the introduction of providing information on the starting pitcher made substantial contributions to the rise in attendance of Pacific League games. Furthermore, it seems appropriate to propose that the home team's starting pitcher announcement has a greater effect upon attendance than the visiting team's owing to the larger demand for the home team ${ }^{4}$. It seems reasonable to postulate the following hypothesis ${ }^{5}$ :

Hypothesis 1: If fans know who will be the starting pitcher, then the degree of his popularity will be positively associated with game attendance. Further, this effect is greater for the home team pitcher than for the visiting one.

It is widely known that the Japan Professional Football League (JPFL), inaugurated in 1993, has become very popular mainly due to the people's affection for their hometown teams (Nihon Keizai Newspaper (ed.) 2005). In contrast, as stated earlier, JPBL has developed considerably thanks to the diffusion of broadcasting. After the emergence of JPFL, regarded as a substitute for JPBL, it was pronounced that the popularity of JPBL drastically declined (Yamamura and Shin 2008 b). The introduction of JPFL put

\footnotetext{
4 As shown in Table 1, there is hardly any difference between home team and visitor team win rates for either league. Total win rate of home and visitor teams does not reach 1 since there are some games ended in a draw.

5 A number of prior research has examined how the characteristics of starting pitchers affects the outcomes of attendance (Scully 1974, Hill et al. 1982, Bruggink et al 1996).
} 
competitive pressure on JPBL in the professional sports market. Such conditions induced the Pacific League to consider it very critical to attach importance to the team's home town and local fans while the Central League is more likely to stick to the past way presumably due to the past experience of success.

Sadaharu Oh was the supervisor of the Fukuoka Hawks, located in the Kyushu region and regarded as the dominant team in the Pacific League ${ }^{6}$. He has the principle of attaching importance to the home town in constructing the team. According to Oh, the key players of the Hawks mostly came from Kyushu, which is the southern region of Japan and approximately $900 \mathrm{~km}$ distant from Tokyo. The players brought up in the home town have become the main force and play an important role in games, leading local people to love and support the team (Nagatani 2005) ${ }^{7}$. This suggests that it is very important to foster local star players to attract local fans ${ }^{8}$.

Under the practice of releasing the name of the starting pitcher prior to games, more attractive pitchers are put on the starting roster, resulting in increased in attendance. As pointed out by Gwartney and Haworth (1974), in MLB, starting black players may attract black customers who had previously attended games mainly for the reason that they wanted to enjoy games in the stadium. If of the same logic holds true for local customers, such as schmoozers, then it would be reasonable to assert that the players coming from the town where the game is held will attract local customers who previously have not attended baseball games. On the other hand, if there is customer discrimination against foreign players, then this system would decrease the attendance for games in which the starting pitcher comes from abroad. The situation of foreign players in

\footnotetext{
6 Sadaharu Oh was a prestigious player and member of the Giants during their golden age in the 1960s in which the Giants retained the championship for 9 years. In conjunction with the team dominance and development of JPBL, he became a nationwide superstar. After Oh retired as a player he became supervisor of the Giants from 1984-1988, leading them to a pennant race win, during which time the Giants benefited from the broadcasting effect. From 1995 to 2008 he was supervisor of Pacific League team, the Fukuoka Hawks. When Oh became supervisor, the Hawks were unpopular and weak. The hawks, however, became the most dominant and popular team in the Pacific League, presumably due to the competence of $\mathrm{Oh}$.

7 Oh also pointed out that during his time as a player, the Giants experienced a drop in support of local fans because they focused too much on gaining nationwide popularity(Nagatani 2005).

8 Yoshio Higuchi has also pointed out the importance of fostering local star players in the resurgence of baseball's popularity (Ninomiya and Higuchi 2005, p.1973)
} 
Japan is similar to that of black and minority players in MLB (Irani 1996, Gwartney and Haworth 1974) ${ }^{9}$. Further, such informal social networks and discrimination effects will amplify the popularity of star players because local customers are more likely to become loyal supporters of star players than those unfamiliar to them ${ }^{10}$. These arguments can be summarized by the following hypothesis:

Hypothesis 2: Under the practice of releasing the name of the starting pitcher prior to a game, the magnitude of the star player's effect on attendance would be larger when he comes from a team's hometown. Further, it would also be greater if he is Japanese, rather than foreign.

Before proceeding to the regression analysis, it is useful to first look at the preliminary comparison between the two leagues across the features of starting pitchers. From the top row of Table 2(a) and (b) it can be seen that attendance is statistically larger in cases when the home team's starting pitcher's home town is the same as the team's hometown in the Pacific and Central leagues. On the other hand, attendance does not increase even if the visiting pitcher comes from the home team town, regardless of the league. Looking at the third and forth rows reveals that attendance in PL games is significantly smaller in games where the starting pitcher is foreign, while there is no such effect in CL games. These findings are almost congruent with expectations. Nevertheless, as shown in the results of the CL, characteristics of the starting pitcher partly affects attendance even when no previous information released concerning the starting pitcher. Such an unexpected result calls for additional investigation.

Although baseball has been among the most popular leisure industries in Japan, few researchers have

\footnotetext{
9 Irani (1996) found that the playing time accorded to black players is negatively related to attendance. On the other hand, Gwartney and Haworth(1974) presented the finding that black players do not have a detrimental effect on attendance.

10 Informal social networks are thought to be formed among people characterized by the same ethnicity, generation, etc. Irani (1996) examined how and to what extent the effects of customer discrimination on attendance could have dissipated as the percentage of blacks in the team's city increased. He did not, however, find the substantial effect of percentage of blacks on the attenuation of discrimination against blacks.
} 
attempted to examine how people become fans and decide to attend the baseball games of JPBL. This might partly because exact numbers on attendance rates could not be obtained ${ }^{11}$. In 2004, JPBL confronted this difficulty and carried out a reform because of its substantial decline in popularity (Nihon Keizai Newspaper, 2005, Ninomiya and Higuchi 2005) ${ }^{12}$. As a consequence, accurate attendance figures began to be announced for each game from 2005. Therefore, the availability of accurate data in 2005, 2006, and 2007 enabled me to investigate how and to what extent releasing the name of the starting pitcher affects game attendance by comparing the PL and CL. I use an originally constructed panel data set to examine the above hypotheses above in the following section.

\section{ECONOMETRIC FRAMEWORK AND ESTIMATION RESUTLS}

\section{A. Econometric framework}

To examine the empirical hypotheses raised in the previous section, the basic regression equation takes the following form:

$$
\begin{aligned}
& \operatorname{Ln}(A T T E N)_{i j s t}=\alpha_{1} \operatorname{Ln}(H P A Y)_{i j s t}+\alpha_{2} \operatorname{Ln}(V P A Y)_{i j s t} \\
& +\alpha_{3} \operatorname{Ln}(H P A Y)_{i j s t} * H H O M_{i j s t}+\alpha_{4} \operatorname{Ln}(V P A Y)_{i j s t} * V H O M_{i j s t} \\
& +\alpha_{5} \operatorname{Ln}(H P A Y)_{i j s t} * H F O R E_{j s t}+\alpha_{6} \operatorname{Ln}(V P A Y)_{i j s t} * V F O R E_{j s t} \\
& +\alpha_{7} \operatorname{Ln}(H W I N R)_{i j s t}+\alpha_{8} \operatorname{Ln}(V W I N R)_{i j s t} \\
& +\alpha_{9} \text { WKEND }_{s t}+\alpha_{10} H O L I D_{s t}+\alpha_{11} \operatorname{Ln}(P O P)_{i, s-l}+\alpha_{12} \operatorname{Ln}(P I N C O M)_{i, s-l} \\
& +\delta_{s}+v_{i j}+u_{i j s t},
\end{aligned}
$$

11 It was, however, possible to collect inaccurate attendance numbers which did not reflect actual conditions. Yamamura and Shin (2008b) attempted to examine the determinants of JPBL attendance using the annual data during the 1952-2003 period although the data was not accurate.

12 Decline in popularity is represented, for instance, in the drop of the program ratings of JPBL games (Yamamura and Shin 2008b). 
where $A_{T T E N}{ }_{i j t}$ represents the dependent variable in prefecture $i$, stadium $j$, year $s$, and date of game $t$. $\alpha$ 's represents the regression parameters. $\delta_{s}, v_{i j}, u_{i j s t}$ represent the unobservable specific effects in the $s$ 's year (a fixed effect time vector), the individual effects of $j$ 's stadium in $i$ 's prefecture (a fixed effects prefecture vector) and an error term, respectively ${ }^{13}$. A panel structure is used for the data set in this study. In particular, special attention needs to be paid to the omitted variable bias stemming from unobservable individual stadium specific effects such as the ticket price of each stadium, and access to the stadium. In addition, various substitute goods often exist in the surrounding area ${ }^{14}$. With the aim of controlling for these variables, a fixed effects estimation is employed ${ }^{15}$. Year dummies were also incorporated to control for $\delta_{s}$, which represents conditional and structural changes at the macro level which could affect the demand for baseball games.

Besides the pitcher, the other members of the team do not greatly vary during the season. The team structure can be considered to be a fixed effect, which is controlled for by a fixed effects estimation. The regular members would be different in each season because team strategy appears to depend upon the performance of the past season. If this is the case, year dummies are thought to alleviate such effects. With

13 The fact that the dependent variables are estimated coefficients from previous regressions may lead to heteroskedastic disturbances. Thus, the $t$ statistics I report in all estimations are based on a heteroskedasticity-consistent estimate of the variance-covariance matrix.

14 Examples of substitutes are other professional baseball teams, professional football team's, and other amusement facilities.

15 It is very difficult to incorporate the ticket price as an independent variable because various types of tickets are sold and therefore prices vary within a stadium (Puro-yakyu Senshu Meikan, various years). There are two choices to measure the ticket price. First, as discussed in the literature (e.g., Noll 1974, Schmidt and Berri 2001 ), there is a way to constructed average price by weighting the ticket prices for each class of seats in each stadium by that class of seat's share of stadium capacity. The scarcity of data about class of seats prevents me from constructing the price data. Second, average realized ticket price can be obtained by dividing ticket revenue by attendance (Kahane and Shmanske 1997). Nonetheless, it is impossible to obtain figures for ticket revenue and therefore to calculate price. Knowles et al (1992), however, asserted that within a given season ticket prices do not vary and therefore omission of price variables would not result in a bias. The sets of prices in each stadium were almost unchanged during the studied period 2005-2007 (Puro-yakyu Senshu Meikan, various years). This means that the ticket price of each stadium can be considered to be a time-invariant fixed effect. Accordingly, the fixed effect estimation allows me to control for a price effect since the unobservable stadium specific effects can be controlled for. In addition to price, substitute goods such as other professional sports teams and amusement parks also hardly change during the studied period and can thus be controlled for. 
the exception of dummy variables, dependent and independent variables take log form and therefore the values of coefficients can be interpreted as being elastic ${ }^{16}$.

To examine Hypothesis 1, check (HPAY) $)_{i j s t}$ and $(V P A Y)_{i j s t}$ standing for the salary of home team's starting pitcher and that of the visiting one, respectively. There are a number of measures of a team's popularity, such as the performance of the past years, player numbers selected to play in all star games, number of championship titles, etc. In this paper, salary is considered to represent these factors and popularity because not only the player's record but also a subjective charm might attract fans and therefore increase the revenues of team. Further, it is reasonable to assume that team revenue is positively associated with the salary of its players. As a consequence, the extent of a player's popularity and his 'stardom' is thought to be reflected in their salary. Following the discussion up to this point, the home pitcher would be more attractive locally for home fans than visitor ones even if their performance and charm do not differ generally. If Hypothesis 1 is supported, I expect that the signs of $\operatorname{Ln}(H P A Y)_{i j s t}$ and $\operatorname{Ln}(V P A Y)_{i j s t}$ are positive and the magnitude of $\operatorname{Ln}(H P A Y)_{i j s t}$ are larger than that of $\operatorname{Ln}(V P A Y)_{i j s t}$ in the PL estimation. However, there would be no effect on them in CL because of the lack of information about the starting pitcher.

To capture the characteristics of the starting pitcher, I defined various dummies as follows. HHOM is 1 when the home team's starting pitcher's hometown is the town in which game was held, otherwise it is 0 . VHOM is 1 when the visiting team's starting pitcher's hometown is the town in which the game was held, otherwise it is 0. HFORE is 1 when the home team's starting pitcher is a foreigner, otherwise it is 0. VFORE is 1 when the visiting team's starting pitcher is a foreigner, otherwise it is 0 . To examine Hypothesis 2 concerning the starting pitcher's hometown effect on his local popularity, the interaction of $\operatorname{Ln}(H P A Y)_{i j s t}$ with $H H O M$, and of $\operatorname{Ln}(V P A Y)_{i j s t}$ with $V H O M$, are incorporated. Their anticipated signs are positive, indicating that the salary of starting pitchers makes a greater contribution to a rise in attendance if he comes from the team's hometown. Furthermore, with the aim of determining the effect of foreigners on attendance, the interaction of

16 Zero cannot be changed to log form and hence dummy variables are not log form. 
$\operatorname{Ln}(H P A Y)_{i j s t}$ with HFORE, of $\operatorname{Ln}(V P A Y)_{i j s t}$ with VFORE, are incorporated. They are predicted to take negative signs since discrimination against foreign players would decrease his popularity, leading to a decline in attendance.

Following the previous literatures (e.g., Bruggink et al. 1996, Irani 1996, Kahane and Shmanske, Knowles et al. 1992, Whitney 1988), I include various control variables as below.

The home team plays a match against a visiting team, and therefore the value of a game is determined not only by the quality of the home team but also by the visiting team. Therefore, each team's winning percentages of the current season are incorporated, represented as $\operatorname{Ln}(H W I N R)$ and $\operatorname{Ln}($ VWINR). It seems reasonable that fans enjoy seeing their team win and would like to see their team's win the championship. This leads me to expect the signs of these variables to be positive.

Because fewer people work on weekends and national holiday, the opportunity cost of attending games at these times is lower. Inevitably, both of these dummy variables denoted as WKEND and HOLID are expected to have a positive effect on attendance.

The population of the prefecture to which the home town belongs is thought to represent the market size. The larger the potential market in which a team plays, the greater the attendance. Accordingly, the anticipated effect of $\operatorname{Ln}(P O P)$, standing for population, is positive. The effect of per capita income is thought to reflect whether a baseball game is an inferior or superior good. The influence of income, $\operatorname{Ln}($ PINCOM), varies widely in the existing literature. Some studies have suggested that its effects are negative (Noll 1974, Bruggink et al. 1996), while other studies suggest that it is positive (Knowles et al. 1992, Kahane and Shmanske 1997). Whitney (1988) suggested the effect is different between the National and American leagues in MLB.

\section{B. Results and discussion (OLS estimation)}

As stated earlier, data is the game level during the 2005-2007 seasons, the total observation of the Pacific 
League and that of the Central League are 785 and 805 , respectively ${ }^{17}$. Game attendance, team win rate, weekend dummy, and holiday dummy were collected from the baseball yearbook, Nihon Puro-yakyu Kiroku Nenkan (various years). Starting pitcher's characteristics are available from the directory of baseball players, Puro-yakyu Senshu Meikan (various years). The population and per capita income of the prefecture in which home teams are located can be obtained from the website of the Cabinet Office of Japan ${ }^{18}$.

Table 3 presents the results of the OLS estimation and Table 4 provides the fixed effects estimation. In Tables 3 and 4, columns (1), (3), (5), and (7) exhibit the results of the PL, whereas (2), (4), (6), and (8) show those of the CL. Now, let me begin by looking at Table 3 .

It can be seen from the first and second rows of Table 3 that $L n(H P A Y)$ and $L n(V P A Y)$ have a positive effect on attendance. In the PL, $\operatorname{Ln}(H P A Y)$ is statistically significant at the $1 \%$ level, whereas $\operatorname{Ln}(V P A Y)$ is insignificant. What is more, the values of $\operatorname{Ln}(H P A Y)$ are 0.06 , which is approximately 6 times larger than that of $\operatorname{Ln}(V P A Y)$. Becaues a pitcher's salary is considered a proxy for his quality, this implies that a $1 \%$ increase in the salary of the home team's starting pitcher leads to $0.06 \%$ augmentation in attendance, whereas a $1 \%$ higher amount in the visiting team's pitcher results in only a $0.01 \%$ rise in attendance. In the case of the CL, in contrast with the PL, $\operatorname{Ln}(V P A Y)$ are the statistically significant at the $1 \%$ level whereas $\operatorname{Ln}(H P A Y)$ are insignificant. The magnitude of $\operatorname{Ln}(V P A Y)$ is larger than that of $\operatorname{Ln}(H P A Y)$. The results of the PL are consistent with Hypothesis 1 . Nonetheless, the finding that game attendance is affected by the characteristics of the starting pitcher in the $\mathrm{CL}$ is not consistent. Some different interpretations are possible. During the season, starting pitchers are regularly determined by rotation, which enables fans to predict the starting pitcher even if there was no formal announcement. Even if this is true, it seems strange that the visiting team's starting pitcher make significantly affects attendance. I interpret that in the OLS estimation various key factors

17 There is no information concerning freshman's salary so that the games in which freshman was the starting pitcher are removed from samples.

18 Population and per capita income can be obtained at

http://www.esri.cao.go.jp/jp/sna/kenmin/h17/main.html. The past year's, s-1, population and per capita income are used instead of the current year's data since the cause recent data are not available. 
were not captured, such as the ticket price, number of substitutes, or the resting periods of players, leading the results to suffer from an estimation bias.

Turning to the interaction terms of $\operatorname{Ln}(H P A Y)^{*} H H O M$ and $\operatorname{Ln}(V P A Y)^{*} V H O M$, with the exception of $L n(V P A Y)^{*} V H O M$ in the PL estimation, all effects are positive. Note that $\operatorname{Ln}(H P A Y) * H H O M$ of the PL estimation is only statistically significant at the $1 \%$ level and its absolute values are strikingly larger than that of others variables. This indicates that the salary of a starting pitcher who comes from a team's hometown has a greater effect on attendance than that of one coming from the outside only when the stating pitcher is announced beforehand. With respect to the $\operatorname{Ln}(H P A Y)^{*} H F O R E$, and $\operatorname{Ln}(V P A Y)^{*} V F O R E$, as exhibited in columns (3) and (7), their coefficients of the PL take have a negative effect, and in particular $\operatorname{Ln}(V P A Y) * V F O R E$ are statistically significant, indicating that a foreign starting pitcher's salary has a smaller effect on attendance than a Japanese pitcher's salary. This result supports Hypothesis 2. On the other hand, in the CL estimation, $\operatorname{Ln}(H P A Y)^{*} H F O R E$ has an unexpected positive effect, presumably because the starting pitcher is not announced in advance.

As for the various control variables, in line with the prediction, $\operatorname{Ln}(H W I N R)$ and $\operatorname{Ln}(V W I N R)$ have significantly positive effects. Further, the magnitude of the effect of $\operatorname{Ln}(H W I N R)$ is approximately three times larger than that of $\operatorname{Ln}(H W I N R)$, meaning that the home team's win rate has a greater influence on attendance than that of the visiting team. As anticipated previously, WKEND and HOLID have significantly positive effects. These values varied from 0.16 to 0.37 , indicating that attendance on weekends and holidays is larger by 16 to $37 \%$ than on weekdays. Consistent with expectations, the coefficients $\operatorname{Ln}(P O P)$ are positive and statistically significant at the $1 \%$ level. $\operatorname{Ln}($ PINCOM $)$ has a negative effect, which is in line with previous studies (Noll 1974, Bruggink et al. 1996).

\section{Results and discussion (fixed effects estimation)}

Let me switch now to the results of the fixed effects estimation, provided in Table 4. In all estimations of 
the PL, the effects of $\operatorname{Ln}(H P A Y)$ and $\operatorname{Ln}(V P A Y)$ are consistently positive. Magnitudes of $\operatorname{Ln}(H P A Y)$ are approximately 0.03 , which is about three times larger than $\operatorname{Ln}(V P A Y)$. Compared to the results of Table 3, where the home team's fixed effects were not controlled for, even though the magnitude of $\operatorname{Ln}(H P A Y)$ decreased, the statistical significance was not affected. On the other hand, in the results of the CL, Ln(HPAY) has an unexpected negative effect. As for $\operatorname{Ln}(V P A Y)$, its results indicate that they were statistically insignificant and its magnitude remarkably decreased to less than 0.01 in all estimations, despite being predicted to have a positive effect. It follows from what I found in the results of the CL that the salary of a starting pitcher does not have an effect on attendance. Considering the results of $\operatorname{Ln}(H P A Y)$ and $\operatorname{Ln}(V P A Y)$ suggested above jointly, an announcement about a starting pitcher makes a significant and substantial contribution to game attendance, after controlling for the home team's fixed effects. Furthermore, such an impact from the home team's starting pitcher is far larger than that of the visiting team's pitcher, which strongly supports Hypothesis 1.

As for the interaction term, $\operatorname{Ln}(H P A Y) * H H O M$, and $\operatorname{Ln}(V P A Y)^{*} V H O M$ consistently have negative effects, especially $\operatorname{Ln}(V P A Y)^{*} V H O M$, and are statistically significant in the results of the PL. In addition, the magnitude of $\operatorname{Ln}(V P A Y)^{*} V H O M$ is approximately three times larger than that of $\operatorname{Ln}(H P A Y)^{*} H H O M$. These results are almost the same as those in Table 3, suggesting that the results are invariant to the use of different estimation methods and specifications. In contrast with the PL, the results of the CL have unpredicted results in all estimations. As regards $L n(H P A Y)^{*} H F O R$, and $L n(V P A Y)^{*} V F O R E$, in columns (3) and (7) their coefficients in the PL have a negative effect, and $\operatorname{Ln}(V P A Y)^{*} V F O R E$ in particular is statistically significant. In contrast, their results in the CL, shown in columns (4) and (8), have positive effects.

In all, under the practice of announcing starting pitchers, the information of starting pitchers from either team who come from a team's hometown significantly enhance the salary effect, in particular, for the home team's starting pitcher. On the other hand, the salary effect is diminished when the starting pitcher is a foreigner, especially for the visiting team. Nevertheless, these tendencies were not observed at all if fans did not have information regarding the starting pitcher. Consequently, the results are in line with Hypothesis 2. 
With respect to other variables, $\operatorname{Ln}(H W I N R)$ and $\operatorname{Ln}(V W I N R)$ have positive effects in all specifications, while being statistically significant with the exception of $\operatorname{Ln}(H W I N R)$ in the CL estimations. Note that the absolute values of $\operatorname{Ln}(H W I N R)$ are consistently smaller than $\operatorname{Ln}(V W I N R)$, which is contrary to the results of Table 3, indicating that attendance with respect to the home team's win rate is less elastic than that of the visiting team's. I interpret this as indicating that compared to the visiting team's fans, the home team's fans are more interested simply in seeing their home team play rather than the team's performance, presumably due to the their addictive behavior. In particular, the relatively small value and insignificance of the home team's win rate in the $\mathrm{CL}$ is considered to reflect the tendency that the demand behavior of CL fans is more inelastic (Yamamura and Shin 2008a).

WKEND and HOLID were almost the same as Table 3 and therefore hardly affected in the alternative estimation. Although the effects of coefficients for $\operatorname{Ln}(P O P)$ and $\operatorname{Ln}(P I N C O M E)$ are positive and negative respectively, which is the same as in Table 3, their absolute values and t-values were strikingly reduced. It is reasonable to assume that the effects of population and per capita income of the prefecture where the home team is located can mostly be taken into account by the home team's fixed effects and year dummies. This might be the reason why $\operatorname{Ln}(P O P)$ and $\operatorname{Ln}(P I N C O M E)$ hardly affect attendance.

As a whole, the findings presented in this section strongly and consistently support my hypotheses.

\section{CONCLUSION}

It is generally acknowledged that information on the quality of goods is very important for consumer decision making. The quality of a baseball game is determined by various factors, one of which is the player composition of the team. Compared to other positions, which are usually occupied by regular players, the starting pitcher changes each game. Inevitably, it is critical for fans to obtain information about the starting pitchers prior to making a decision on game attendance. In addition, a player's salary is to some extent considered to reflect not only his performance but also the extent of his popularity. In regards to game 
attendance, the popularity of a player appears to depend upon the city in which the game is held, which is due to the consumer discrimination (Becker 1971). It seems reasonable to assert that, other things being equal, fans are likely to prefer home team players to visiting team players. Furthermore, because of informal social connections, they appear to be fond of players whose hometown is identical to the home team's. As a result, the starting pitcher seems to have an effect upon game attendance and the magnitude of this effect relies upon the city in which game is held.

In the case of JPBL, the starting pitcher is announced prior to the game in the PL, but not in the CL. This difference of practice between leagues is expected to have a crucial affect on attendance. Comparing the PL and CL, I attempt to investigate how and to what extent the release of information on the starting pitcher prior to a game affects attendance. The major findings from the fixed effect estimation are as follows:

(1) In the PL, the salary of the home team's starting pitcher is positively related to attendance, while that of the visiting team's is not.

(2) In the CL, neither the salary of the home team's or visiting team's starting pitcher affects game attendance.

(3) In the case of the PL, the positive effect of salary on attendance is larger when the starting pitcher's is from the same hometown as that of the team when a game is held in that town. On the other hand, the effect of salary declines when the starting pitcher is a foreigner.

Based on these findings I argue that the release of information on a pitcher increases demand for local 'star players', whereby local people are more likely to attend a game. This is presumably because the informal social network plays a critical role in augmenting game attendance (Putnam 2000). The practice of announcing pitchers prior to a game in the PL is suitable for the strategy of catering to the demands of local fans. 


\section{REFERENCES}

Andersen, T. and J. La Croix. "Customer Racial Discrimination in Major League Baseball.” Economic Inquiry, 29, 1991, 665-677.

Becker, G. The Economics of Discrimination. Chicago: University of Chicago Press, 1971.

Bruggink, T. and J. Eaton. "Rebuilding Attendance in Major League Baseball: The Demand for Individual Games.” in Baseball Economics: Current Research, edited by J. Fizel, E. Bustafson, and 1. Hadley. Westport, CT: Praeger, 1996, 9-31.

Burdekin, R. and T. Idson. "Customer Preferences, Attendance and the Racial Structure of Professional Basketball Teams.” Applied Economics, 23, 1991, 179-186.

"Chiiki Micchaku Minori no Pa" (Region Oriented Pacific League Turned Out to be Successful). Nihon Keizai Newspaper, 1 January 2008. [in Japanese].

Eckard, E.W. "Free Agency, Competitive Balance, and Diminishing Returns to Pennant Contention.” Economic Inquiry, 39, 2001, 430-443.

Gwartney, J. and C. Haworth. "Employer Costs and Discrimination: The Case of Baseball." Journal of Political Economy, 82, 1974, 873-881.

Hill, J., J. Madura., and R. Zuber. "The Short-ran Demand for Major League Baseball," Atlantic Economic Journal, 10, 1982, 31-55.

Hoang, H., and D. Rascher. "The NBA, Exit Discrimination and Career Earnings.” Industrial Relations, 38, 1999, 69-91.

Hunt, J.W. Jr, and K. A. Lewis. "Dominance, Recontracting, and the Reserve Clause: Major League Baseball." American Economic Review, 66, 1976, 936-943.

Irani, D. "Estimating Customer Discrimination in Baseball Using Panel Data: 1972-1991," in Baseball Economics: Current Research, edited by J. Fizel, E. Bustafson, and 1. Hadley. Westport, CT: 
Praeger, 1996, 47-61.

Kahn L., and P. Sherer. "Racial Discrimination in Professional Baseball: Evidence from Nielson Ratings." Journal of Labor Economics, 6, 1988, 40-61.

Kahane, L., and S. Shmanske. "Team Roster Turnover and Attendance in Major League Baseball." Applied Economics, 29, 1997, 425-31.

Knowles, G., K.Sherony., and M. Haupert. "The Demand for Major League Baseball: A Test of the Uncertainty of Outcome Hypothesis." American Economist, 36, 1992, 72-80.

Kobayashi, I. Gappei, Baikyaku, Shinkisan-nyu: Takaga... Saredo Puro-yakyu[in Japanese] (Mergers, Sale, New Entrance: No More than Baseball, Still Baseball!), Tokyo: Takarajima-sha, 2004.

La Croix, S., and A. Kawaura. "Rule Changes and Competitive Balance in Japanese Professional Baseball." Economic Inquiry, 3, 1999, 353-368.

Nagatani, O. "Oh Sadaharu ga Katatta Kyukai Kiki. Mo Nagashima-san ni Tayorunowa Yameyoyo” (Sadaharu Oh told that Japan Professional Baseball confront the difficulty and it should to stop rely on the popularity of Mr. Nagashima). Shukan Bunshun, 21 July 2005. [in Japanese].

Nardinelli, C. and C. Simon. "Customer Racial Discrimination in the Market for Memorabilia: The case of Baseball." Quarterly Journal of Economics, 105, 1990, 575-595.

Nihon Keizai Newspaper (ed.). Kyukai Saihen wa Owaranai. (The reorganization of Japan Professional Baseball League would not come to an end). Tokyo, Nihon Keizai Newspaper, 2005. [in Japanese].

Nihon Puro-yakyu Kiroku Nenkan (Baseball Record Book), Tokyo: Baseball Magazine sha, various Years. [in Japanese].

Ninomiya, S., and Y. Higuchi. Nihon Puro-yakyu Kaizo Keikaku. (The plan to reform Japan Professional Baseball League). Tokyo, Nihon Hyoron Sha, 2005. [in Japanese].

Noll, R.G. "Attendance and Price-Setting." In Roger Noll (ed.), Government and the Sports Business. 
Washington, D.C.: The Brookings Institution, 1974, 115-157.

Puro-yakyu Senshu Meikan ( A Directory of Professional Baseball Players), Tokyo: Tkarajima Sha, various Years. [in Japanese].

Putnam, R. Bowling Alone: The Collapse and Revival of American Community, A Touchstone Book, 2000.

Rosen, S. “The Economics of Superstars.” American Economic Review, 71,1981, 845-858.

Schmidt, M., and D. Berri. "Competitive Balance and Attendance: The Case of Major League Baseball." Journal of Sports Economics, 2, 2001, 145-167.

. "The Impact of the 1981 and 1994-1995 strikes on Major League Baseball Attendance: A Time Series Analysis." Applied Economics, 34, 2002, 471-478.

. "The Impact of Labor Strikes on Consumer Demand: An Application to Professional Sports." American Economic Review, 94, 2004, 344-355.

Scully, G. "Discrimination: The Case of Baseball." In Roger Noll (ed.), Government and the Sports Business. Washington, D.C.: The Brookings Institution, 1974,221-274.

Whitney, J. "Winning Games Versus Winning Championships: The Economics of Fan Interest and Team Performance.” Economic Inquiry, 26, 1988, 703-724.

Yamamura, E., and I. Shin. "Convergence, Clustering and Their Effects on Attendance in the Japan Professional Baseball League." Applied Economics, 2008a, forthcoming.

Yamamura, E., and I. Shin. "The Influence of a Leader and Social Interaction on Attendance: The Case of the Japanese Professional Baseball League, 1952-2003.” Journal of Socio Economics, 2008b, forthcoming. 


\section{TABLE 1}

Descriptive statistics

\begin{tabular}{|c|c|c|c|c|c|}
\hline Variables & Definition & Pacific & Central & All & t-value \\
\hline ATTEN & Number of attendance & 20,343 & 27,600 & 24,081 & $14.5^{* *}$ \\
\hline$H P A Y$ & $\begin{array}{l}\text { Salary of home team's starting pitcher } \\
\text { (in millions of Yen) }\end{array}$ & 61 & 83 & 72 & $6.17 * *$ \\
\hline$V P A Y$ & Salary of visitor team's starting pitcher & 63 & 83 & 73 & $5.53^{* *}$ \\
\hline$H W I N R$ & $\begin{array}{l}\text { Home team's win rate during the current } \\
\text { season }\end{array}$ & 0.49 & 0.49 & 0.49 & 0.04 \\
\hline$V W I N R$ & $\begin{array}{l}\text { Visiting team's win rate during the } \\
\text { current season }\end{array}$ & 0.48 & 0.49 & 0.49 & 0.52 \\
\hline HHOM & $\begin{array}{l}\text { Is } 1 \text { when home team starting pitcher's } \\
\text { home town is the town in which game was } \\
\text { held, otherwise } 0 \text {. }\end{array}$ & 0.03 & 0.03 & 0.03 & 0.07 \\
\hline VHOM & $\begin{array}{l}\text { Is } 1 \text { when visitor team starting pitcher's } \\
\text { home town is the town in which game was } \\
\text { held, otherwise } 0 \text {. }\end{array}$ & 0.04 & 0.02 & 0.03 & $2.05^{*}$ \\
\hline HFORE & $\begin{array}{l}\text { Is } 1 \text { when home team starting pitcher is } \\
\text { foreigner, otherwise } 0 .\end{array}$ & 0.16 & 0.16 & 0.16 & 0.02 \\
\hline VFORE & $\begin{array}{l}\text { Is } 1 \text { when visitor team starting pitcher is } \\
\text { foreigner, otherwise } 0 \text {. }\end{array}$ & 0.17 & 0.15 & 0.16 & 1.38 \\
\hline WKEND & $\begin{array}{l}\text { Is } 1 \text { when game was held on weekend, } \\
\text { otherwise } 0 \text {. }\end{array}$ & 0.36 & 0.35 & 0.36 & 0.82 \\
\hline HOLID & $\begin{array}{l}\text { Is } 1 \text { when game was held on holiday, } \\
\text { otherwise } 0 .\end{array}$ & 0.63 & 0.63 & 0.63 & 0.01 \\
\hline$P O P$ & $\begin{array}{l}\text { Population of prefecture in which game was } \\
\text { held (in thousands of Yen). }\end{array}$ & 5,760 & 7,805 & 6,814 & $14.9 * *$ \\
\hline PINCOM & $\begin{array}{l}\text { Per capita income of prefecture in which a } \\
\text { game was held (in thousands of Yen). }\end{array}$ & 3,490 & 2,816 & 3,164 & $24.7 * *$ \\
\hline
\end{tabular}

Notes: $* *$ and * means that difference is significant at the $1 \%$ and $5 \%$ level, respectively. 


\section{TABLE 2}

Comparison of characteristics of starting pitchers

(a) Comparison of average number of game attendance among starting pitcher characteristics. (Pacific League)

\begin{tabular}{|c|c|c|}
\hline $\begin{array}{l}\text { Home team's starting pitcher's hometown } \\
\text { same as the town in which game was held. } \\
\qquad 27,428(37)\end{array}$ & $20,059(923)$ & t-value \\
\hline $\begin{array}{l}\text { Visiting team's starting pitcher's } \\
\text { hometown same as the town in which } \\
\text { game was held. }\end{array}$ & Others & \\
\hline $19.552(38)$ & $20,376(922)$ & 0.61 \\
\hline $\begin{array}{l}\text { Home team's starting pitcher is a } \\
\text { foreigner }\end{array}$ & Others & \\
\hline $18,064(157)$ & $20,789(803)$ & $3.86^{* *}$ \\
\hline $\begin{array}{l}\text { Visiting team's starting pitcher is a } \\
\text { foreigner }\end{array}$ & Others & \\
\hline 19,343 (166) & $20,545(794)$ & $1.68^{*}$ \\
\hline
\end{tabular}

(b) Comparison of average number of game attendance among starting pitcher characteristics. (Central League)

Home team's starting pitcher's home town

Others t-value

same as the town in which game was held.

\begin{tabular}{lll}
$35,570(40)$ & $27,274(980)$ & $3.88^{* *}$ \\
\hline Visiting team's starting pitcher's home & Others
\end{tabular}

town same as the town in which game was

held.

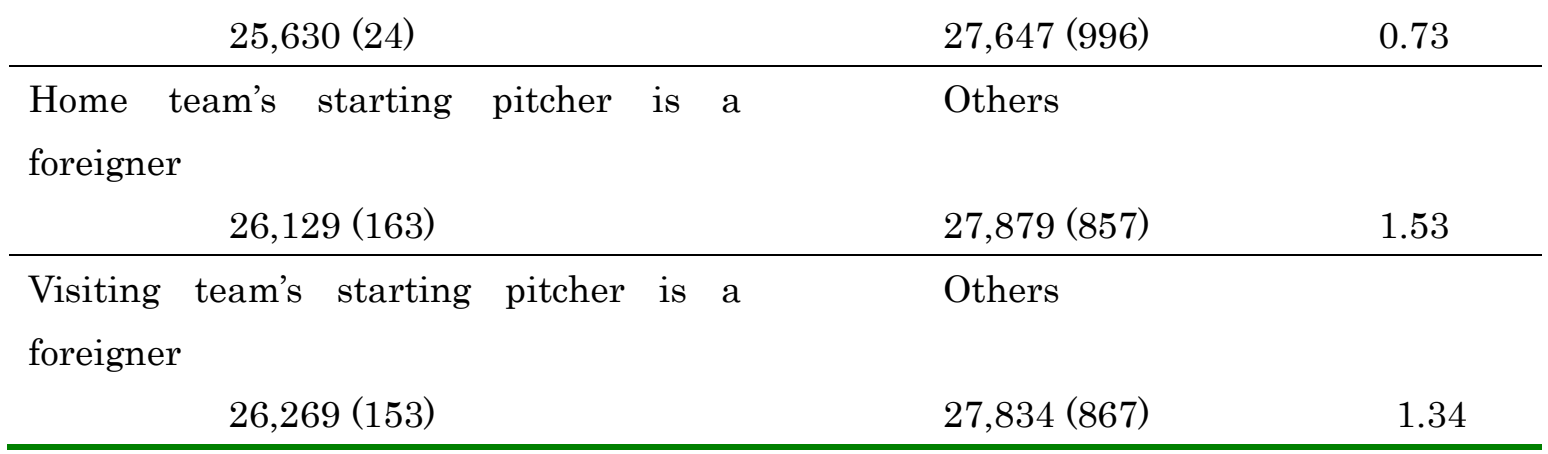

Notes: Values in parentheses are number of observations. ${ }^{* *}$ and $*$ means that difference is significant at the $1 \%$ and $5 \%$ level, respectively. 
TABLE 3

Determinants of attendance (OLS estimation)

\begin{tabular}{|c|c|c|c|c|c|c|c|c|}
\hline Variables & $\begin{array}{c}(1) \\
\text { Pacific }\end{array}$ & $\begin{array}{c}(2) \\
\text { Central }\end{array}$ & $\begin{array}{c}(3) \\
\text { Pacific }\end{array}$ & $\begin{array}{c}(4) \\
\text { Central }\end{array}$ & $\begin{array}{c}(5) \\
\text { Pacific }\end{array}$ & $\begin{array}{c}(6) \\
\text { Central }\end{array}$ & $\begin{array}{c}(7) \\
\text { Pacific }\end{array}$ & $\begin{array}{c}\text { (8) } \\
\text { Central }\end{array}$ \\
\hline \multirow[t]{2}{*}{$\operatorname{Ln}(H P A Y)$} & $0.06 * *$ & 0.01 & $0.06^{* *}$ & 0.005 & $0.06 * *$ & 0.01 & $0.06^{* *}$ & 0.002 \\
\hline & $(5.74)$ & (1.17) & $(5.85)$ & $(0.32)$ & $(5.30)$ & (1.04) & $(5.42)$ & $(0.16)$ \\
\hline \multirow[t]{2}{*}{$\operatorname{Ln}(V P A Y)$} & 0.008 & $0.03^{* *}$ & 0.01 & $0.04^{* *}$ & 0.01 & $0.03^{* *}$ & 0.01 & $0.04^{* *}$ \\
\hline & $(0.75)$ & (2.61) & (1.11) & $(2.98)$ & $(0.93)$ & $(2.53)$ & (1.29) & $(2.89)$ \\
\hline $\operatorname{Ln}(H P A Y) *$ & & & & & $0.28 * *$ & 0.09 & $0.19 * *$ & 0.11 \\
\hline HHOM & & & & & $(4.48)$ & $(0.95)$ & $(4.34)$ & (1.16) \\
\hline \multirow{2}{*}{$\begin{array}{c}\operatorname{Ln}(V P A Y) * \\
V H O M\end{array}$} & & & & & -0.02 & 0.001 & -0.03 & 0.002 \\
\hline & & & & & $(-0.75)$ & $(0.02)$ & $(-0.92)$ & $(0.03)$ \\
\hline $\operatorname{Ln}(H P A Y) *$ & & & -0.04 & $0.25^{* *}$ & & & -0.04 & $0.25^{* *}$ \\
\hline HFORE & & & $(-0.75)$ & $(5.40)$ & & & $(-0.71)$ & $(5.43)$ \\
\hline $\operatorname{Ln}(V P A Y) *$ & & & $-0.13^{*}$ & -0.09 & & & $-0.13^{*}$ & -0.09 \\
\hline VFORE & & & $(-2.27)$ & $(-1.46)$ & & & $(-2.25)$ & $(-1.46)$ \\
\hline \multirow[t]{2}{*}{$\operatorname{Ln}(H W I N R)$} & $0.42^{* *}$ & $1.18 * *$ & $0.41^{* *}$ & $1.17 * *$ & $0.41 * *$ & $1.18 * *$ & $0.41^{* *}$ & $1.17 * *$ \\
\hline & $(7.58)$ & $(14.3)$ & $(7.44)$ & $(14.3)$ & $(7.56)$ & (14.3) & $(7.43)$ & $(14.3)$ \\
\hline \multirow[t]{2}{*}{$\operatorname{Ln}(V W I N R)$} & $0.17^{* *}$ & $0.37 * *$ & $0.17^{* *}$ & $0.40^{* *}$ & $0.17 * *$ & $0.37 * *$ & $0.17 * *$ & $0.40 * *$ \\
\hline & $(3.86)$ & $(4.57)$ & $(3.81)$ & $(4.83)$ & (3.78) & $(4.57)$ & (3.73) & $(4.84)$ \\
\hline \multirow[t]{2}{*}{ WKEND } & $0.27 * *$ & $0.16^{* *}$ & $0.27 * *$ & $0.16^{* *}$ & $0.28 * *$ & $0.16^{* *}$ & $0.28^{* *}$ & $0.16^{* *}$ \\
\hline & (13.1) & $(4.74)$ & (13.1) & $(4.69)$ & (13.3) & $(4.68)$ & (13.3) & $(4.62)$ \\
\hline \multirow[t]{2}{*}{ HOLID } & $0.37 * *$ & $0.28 * *$ & $0.37 * *$ & $0.18 * *$ & $0.37 * *$ & $0.17 * *$ & $0.37 * *$ & $0.17 * *$ \\
\hline & $(9.51)$ & (3.96) & $(9.54)$ & $(3.04)$ & $(9.60)$ & $(2.91)$ & (9.63) & $(2.98)$ \\
\hline \multirow[t]{2}{*}{$\operatorname{Ln}(P O P)$} & $0.35^{* *}$ & $0.34^{* *}$ & $0.35^{* *}$ & $0.32 * *$ & $0.35^{* *}$ & $0.34 * *$ & $0.35^{* *}$ & $0.33^{* *}$ \\
\hline & $(7.69)$ & (5.39) & $(7.84)$ & (5.12) & $(7.71)$ & $(5.40)$ & $(7.86)$ & (5.15) \\
\hline \multirow[t]{2}{*}{$\operatorname{Ln}(P I N C O M)$} & $-3.14^{* *}$ & $-0.47 * *$ & -3.20 & $-0.48 * *$ & $-3.11 * *$ & $-0.49 * *$ & $-3.15^{* *}$ & $-0.50 * *$ \\
\hline & $(-12.0)$ & $(-3.06)$ & $(-12.1)$ & $(-3.15)$ & $(-11.7)$ & $(-3.11)$ & $(-11.8)$ & $(-3.22)$ \\
\hline$R$-square & 0.44 & 0.31 & 0.45 & 0.32 & 0.45 & 0.31 & 0.45 & 0.32 \\
\hline Observations & 785 & 810 & 785 & 810 & 785 & 810 & 785 & 810 \\
\hline
\end{tabular}

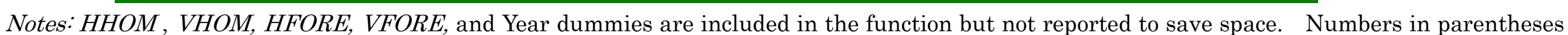
are t-value calculated by robust standard error. $\quad * *$ and * means statistically significant at the $1 \%$ and $5 \%$ level, respectively. 
TABLE 4

Determinants of attendance (Fixed Effects estimation)

\begin{tabular}{|c|c|c|c|c|c|c|c|c|}
\hline Variables & $\begin{array}{c}(1) \\
\text { Pacific }\end{array}$ & $\begin{array}{c}(2) \\
\text { Central }\end{array}$ & $\begin{array}{c}(3) \\
\text { Pacific }\end{array}$ & $\begin{array}{c}(4) \\
\text { Central }\end{array}$ & $\begin{array}{c}(5) \\
\text { Pacific }\end{array}$ & $\begin{array}{c}(6) \\
\text { Central }\end{array}$ & $\begin{array}{c}(7) \\
\text { Pacific }\end{array}$ & $\begin{array}{c}(8) \\
\text { Central }\end{array}$ \\
\hline \multirow[t]{2}{*}{$\operatorname{Ln}(H P A Y)$} & $0.03 * *$ & -0.003 & $0.03^{* *}$ & -0.006 & $0.02 * *$ & -0.003 & $0.02 * *$ & -0.006 \\
\hline & $(3.02)$ & $(-0.40)$ & (3.15) & $(-0.68)$ & $(2.72)$ & $(-0.38)$ & $(2.84)$ & $(-0.65)$ \\
\hline \multirow[t]{2}{*}{$\operatorname{Ln}(V P A Y)$} & 0.01 & 0.004 & 0.01 & 0.004 & 0.008 & 0.003 & 0.01 & 0.003 \\
\hline & (1.07) & $(0.54)$ & (1.42) & $(0.54)$ & $(0.89)$ & $(0.38)$ & $(1.25)$ & $(0.37)$ \\
\hline $\operatorname{Ln}(H P A Y)^{*}$ & & & & & $0.12^{* *}$ & -0.002 & $0.12^{* *}$ & 0.001 \\
\hline HHOM & & & & & (3.15) & $(-0.08)$ & (3.06) & $(0.05)$ \\
\hline $\operatorname{Ln}(V P A Y) *$ & & & & & 0.04 & 0.03 & 0.03 & 0.03 \\
\hline VHOM & & & & & (1.27) & $(0.66)$ & (1.10) & $(0.69)$ \\
\hline $\operatorname{Ln}(H P A Y) *$ & & & -0.03 & $0.05^{*}$ & & & -0.02 & $0.05^{*}$ \\
\hline HFORE & & & $(-0.62)$ & (1.90) & & & $(-0.52)$ & $(1.91)$ \\
\hline $\operatorname{Ln}(V P A Y) *$ & & & $-0.10^{*}$ & 0.01 & & & $-0.10^{*}$ & 0.01 \\
\hline VFORE & & & $(-1.94)$ & $(0.29)$ & & & $(-1.88)$ & $(0.33)$ \\
\hline \multirow[t]{2}{*}{$\operatorname{Ln}(H W I N R)$} & $0.11^{*}$ & 0.10 & $0.10^{*}$ & 0.10 & $0.11^{*}$ & 0.10 & $0.11^{*}$ & 0.10 \\
\hline & $(1.82)$ & (1.60) & (1.73) & $(1.59)$ & (1.89) & (1.61) & (1.81) & $(1.60)$ \\
\hline \multirow[t]{2}{*}{$\operatorname{Ln}(V W I N R)$} & $0.17 * *$ & $0.22 * *$ & $0.17 * *$ & $0.22 * *$ & $0.17 * *$ & $0.22 * *$ & $0.17 * *$ & $0.22 * *$ \\
\hline & $(4.72)$ & $(4.95)$ & $(4.66)$ & $(4.98)$ & $(4.77)$ & $(4.95)$ & $(4.70)$ & $(4.98)$ \\
\hline \multirow[t]{2}{*}{$W K E N D$} & $0.26^{* *}$ & $0.19 * *$ & $0.26 * *$ & $0.19 * *$ & $0.27 * *$ & $0.19 * *$ & $0.27 * *$ & $0.19 * *$ \\
\hline & (14.8) & (8.73) & (14.8) & $(8.69)$ & $(15.0)$ & $(8.62)$ & (14.9) & $(8.57)$ \\
\hline \multirow[t]{2}{*}{ HOLID } & $0.36^{* *}$ & $0.18^{* *}$ & $0.36 * *$ & $0.18^{* *}$ & $0.36 * *$ & $0.18 * *$ & $0.36 * *$ & $0.18 * *$ \\
\hline & $(8.76)$ & $(4.95)$ & $(8.82)$ & $(5.01)$ & $(8.81)$ & (4.93) & $(8.85)$ & $(4.99)$ \\
\hline \multirow[t]{2}{*}{$\operatorname{Ln}(P O P)$} & 0.05 & 0.37 & 0.09 & 0.13 & 0.14 & 0.28 & 0.18 & 0.04 \\
\hline & $(0.13)$ & $(0.05)$ & $(0.23)$ & $(0.02)$ & $(0.34)$ & $(0.04)$ & $(0.45)$ & $(0.01)$ \\
\hline \multirow[t]{2}{*}{$\operatorname{Ln}(P I N C O M)$} & -0.50 & -2.15 & -0.69 & -2.01 & -0.80 & -2.13 & -1.00 & -2.00 \\
\hline & $(-0.30)$ & $(-1.22)$ & $(-0.41)$ & $(-1.14)$ & $(-0.47)$ & $(-1.21)$ & $(-0.58)$ & $(-1.13)$ \\
\hline$R$-square & 0.29 & 0.16 & 0.29 & 0.15 & 0.29 & 0.15 & 0.30 & 0.16 \\
\hline Observations & 785 & 810 & 785 & 810 & 785 & 810 & 785 & 810 \\
\hline
\end{tabular}

Notes: HHOM, VHOM, HFORE, VFORE, and Year dummies are included in the function but not reported to save space. Numbers in parentheses are t-value calculated by robust standard error. ** and * means statistically significant at the $1 \%$ and $5 \%$ level, respectively. 